\title{
Microwave-Assisted Rapid Green Synthesis of Gold Nanoparticles Using Seed Extract of Trachyspermum ammi: ROS Mediated Biofilm Inhibition and Anticancer Activity
}

\author{
Kahkashan Perveen ${ }^{1,+}+{ }^{\oplus}$, Fohad Mabood Husain ${ }^{2, *,+}$, Faizan Abul Qais ${ }^{3}{ }^{\circledR}$, Altaf Khan ${ }^{4}$, Suhail Razak ${ }^{5, *}$, \\ Tayyaba Afsar ${ }^{5}$, Pravej Alam ${ }^{6}$, Ali M. Almajwal ${ }^{5}$ and Mahmoud M. A. Abulmeaty ${ }^{5}$ (i) \\ 1 Department of Botany and Microbiology, College of Science, King Saud University, \\ 2460, Riyadh 11451, Saudi Arabia; kperveen@ksu.edu.sa \\ 2 Department of Food Science and Nutrition, College of Food and Agriculture Sciences, King Saud University, \\ 2460, Riyadh 11451, Saudi Arabia \\ 3 Department of Ag. Microbiology, Aligarh Muslim University, Aligarh 202002, India; \\ faizanabulqais@gmail.com \\ 4 Central Laboratory, Department of Pharmacology and Toxicology, College of Pharmacy, \\ King Saud University, 2460, Riyadh 11451, Saudi Arabia; altkhan@ksu.edu.sa \\ 5 Department of Community Health Sciences, College of Applied Medical Sciences, King Saud University, \\ 2460, Riyadh 11451, Saudi Arabia; tayyabaafsar12@gmail.com (T.A.); aalmajwal@ksu.edu.sa (A.M.A.); \\ mabulmeaty@ksu.edu.sa (M.M.A.A.) \\ 6 Department of Biology, College of Science and Humanities, Prince Sattam bin Abdulaziz University, \\ Alkharj 11942, Saudi Arabia; alamprez@gmail.com \\ check for \\ updates \\ * Correspondence: fhusain@ksu.edu.sa (F.M.H.); smarazi@ksu.edu.sa (S.R.) \\ + These authors contributed equally to this work.
}

Citation: Perveen, K.; Husain, F.M.; Qais, F.A.; Khan, A.; Razak, S.; Afsar, T.; Alam, P.; Almajwal, A.M; Abulmeaty, M.MA MicrowaveAssisted Rapid Green Synthesis of Gold Nanoparticles Using Seed Extract of Trachyspermum ammi: ROS Mediated Biofilm Inhibition and Anticancer Activity. Biomolecules 2021, 11, 197. https://doi.org/10.3390/ biom11020197

Academic Editor: Bilal Haider Abbasi Received: 31 December 2020

Accepted: 19 January 2021

Published: 30 January 2021

Publisher's Note: MDPI stays neutral with regard to jurisdictional claims in published maps and institutional affiliations.

Copyright: () 2021 by the authors. Licensee MDPI, Basel, Switzerland. This article is an open access article distributed under the terms and conditions of the Creative Commons Attribution (CC BY) license (https:// creativecommons.org/licenses/by/ $4.0 /)$.
Abstract: Green synthesis of metal nanoparticles using plant extracts as capping and reducing agents for the biomedical applications has received considerable attention. Moreover, emergence and spread of multidrug resistance among bacterial pathogens has become a major health concern and lookout for novel alternative effective drugs has gained momentum. In current study, we synthesized gold nanoparticles using the seed extract of Trachyspermum ammi (TA-AuNPs), assessed its efficacy against drug resistant biofilms of Listeria monocytogenes and Serratia marcescens, and evaluated its anticancer potential against HepG2 cancer cell lines. Microwave-assisted green synthesis of gold nanoparticles was carried out and characterization was done using UV-vis spectroscopy, X-ray diffraction (XRD), transmission electron microscopy (TEM), and dynamic light scattering (DLS). Most nanoparticles were observed as spherical and spheroidal with few anisotropies with an average crystalline size of $16.63 \mathrm{~nm}$. Synthesized TA-AuNPs demonstrated significant biofilm inhibitory activity against L. monocytogenes (73\%) as well as S. marcescens (81\%). Exopolysaccharide (EPS), motility, and $\mathrm{CSH}$, key elements that facilitate the formation and maintenance of biofilm were also inhibited significantly at the tested sub-minimum inhibitory concentrations (sub-MICs). Further, TAAuNPs effectively obliterated preformed mature biofilms of S. marcescens and L. monocytogenes by $64 \%$ and 58\%, respectively. Induction of intracellular ROS production in TA-AuNPs treated bacterial cells could be the plausible mechanism for the reduced biofilm formation in test pathogens. Administration of TA-AuNPs resulted in the arrest of cellular proliferation in a concentration-dependent manner. TA-AuNPs decrease the intracellular GSH in HepG2 cancer cell lines, cells become more prone to ROS generation, hence induce apoptosis. Thus, this work proposes a new eco-friendly and rapid approach for fabricating NPs which can be exploited for multifarious biomedical applications.

Keywords: gold nanoparticles; green synthesis; Trachyspermum ammi; antibiofilm; anticancer; HepG2 cell lines

\section{Introduction}

Nanobiotechnology is one the most promising and emerging disciplines of science that emphasizes the development of new materials that can be used in healthcare and 
environmental settings [1,2]. The interest in nanomaterials has increased owing to their novel optoelectronic, physicochemical, and magnetic properties compared to their bulk form [3]. The novel biological, chemical, or physical properties of nanomaterials is mainly because of their size (usually less than $100 \mathrm{~nm}$ ) that increases their surface area to volume ratios drastically. The most common methods for the synthesis of metal nanoparticles are chemical, physical, and biological methods. In last two decades, the fabrication of metal nanoparticles using biological materials have obtained considerable attention and scientists have developed numerous novel methods of the green synthesis [4,5]. The biological synthesis (commonly called as green synthesis) of nanomaterials is advantageous over other procedures owing to the use of renewable biological materials and without producing toxic byproducts [6,7]. The green synthesis of nanoparticles used biological entities such as plant materials, microbes, etc. Another advantage of biological synthesis is its ability to produce stability nanomaterials with precise dimensions at the economic cost [8]. However, there are certain limitations/disadvantages associated with the green synthesis of metallic nanoparticles. The major disadvantage is the changes in phytochemical profile of the plant extracts due to seasonal or climate variations that may affect the synthesis procedures and bioactivity. Such changes may lead to concerns regarding the reproducibility of NPs with the same characteristics [9]. Moreover, green synthesis of metals nanoparticles is usually a one-step procedure and sometimes, nanoparticles can be prepared even in a few minutes [10]. Therefore, the green synthesis of metal nanoparticles for biomedical applications has received considerable attention due to their possibility of being developed as novel material with biological applications [11,12].

In last few decades, there has been tremendous increase in the emergence and spread of drug resistance among bacterial pathogens. This antimicrobial resistance is now a global concern as it has become one of the major contributors in mortality and morbidity diseases [13]. Moreover, multiple drug-resistance also worsens the treatment of other infections associated with chronic illness such as diabetes and cancer by reducing the effectiveness of antibiotics [14,15]. Earlier it was thought that bacteria grow in planktonic state, but later it was found that most bacteria live in complex structures called biofilms. The bacterial biofilms are complex systems comprised of bacterial communities and extracellular polymeric substances (EPS). The EPS act as protective barrier from external environment [16]. In biofilms, there is altered expression of many phenotypes (mainly virulent) compared to planktonic growth. The importance of biofilms can be understood from the National Institute of Health (NIH) estimates that roughly $80 \%$ of infections are encouraged and established by biofilms [17,18]. A vast majority of infections are caused due to the development of biofilms either by pathogenic or opportunistic pathogens $[19,20]$.

Bacteria residing in human gut and skin as normal flora are harmless and perform a number of important functions for the host [21]. However, there are certain bacteria which are pathogenic in nature. One of the common entry points of such pathogenic bacteria is through the gastrointestinal tract through which foodborne pathogens enter. Such foodborne pathogens enter usually come from contaminated food and water. Foodborne pathogens are a major cause of food poisoning and foodborne diseases and hence pose serious threat to human health and food safety [22]. The food gets contaminated by many bacteria during processing, harvesting, handling operations, and transportation [23]. The food spoilage by microbes is the major cause of spoilage that poses a human burden for food industry [24]. The major foodborne pathogens are Acinetobacter spp., Bacillus cereus, B. subtilis, Citrobacter koseri, Campylobacter jejuni, Serratia marcescens, Clostridium difficile, E. cloacae, Escherichia coli, Klebsiella spp., Listeria monocytogenes, Staphylococcus aureus, Vibrio cholerae etc. [25,26].

In this study, gold nanoparticles were synthesized using seed extract of Trachyspermum ammi. The nanoparticles were characterized using UV-vis spectroscopy, X-ray diffraction (XRD), transmission electron microscopy (TEM), and dynamic light scattering (DLS). The antibiofilm activity of gold nanoparticles was checked against two foodborne bacterial 
pathogens viz Serratia marcescens and Listeria monocytogenes. Moreover, the anticancer activity was also assessed against HepG2 cell line.

\section{Material and Methods}

2.1. Synthesis and Characterization of Gold Nanoparticles (AuNPS) Using T. ammi Seed Extract

For the preparation of aqueous extract of Trachyspermum ammi seeds, $20 \mathrm{~g}$ seed powder was mixed in $500 \mathrm{~mL}$ double distilled water. The suspension was left for extract for $24 \mathrm{~h}$ followed by centrifugation to settle down the debris. The extract was filtered with $0.22 \mu \mathrm{m}$ filter and stored at $-20{ }^{\circ} \mathrm{C}$ for further use. The method synthesis was adopted from an earlier report [27]. A $10 \mathrm{mM}$ stock solution of $\mathrm{HAuCl}_{4}$ was prepared in double distilled water. For the synthesis of gold nanoparticles, $6 \mathrm{~mL} \mathrm{~T}$. ammi $\mathrm{ml}$ extract was added to $2 \mathrm{~mL} \mathrm{HAuCl}_{4}$ solution and placed on a magnetic stirrer for proper mixing for $30 \mathrm{~min}$. The reaction mixture was then placed in microwave oven for $2 \min (2.45 \mathrm{GHz}, 300 \mathrm{~W})$. Following microwave irradiation, the colour of the reaction mixture changed from light yellow color to ruby red indicating the formation of gold nanoparticles. The colloidal suspension of gold nanoparticles was centrifuged at 20,000 rpm for $30 \mathrm{~min}$ to pellet down the nanoparticles.

The preliminary characterization of gold nanoparticles was done by observing the UV-vis spectrum using Shimadzu UV1900. The absorption spectrum was recorded from 350 to $700 \mathrm{~nm}$ using double distilled as blank.

The X-ray diffraction pattern analysis of gold nanoparticles was performed using X-ray diffractometer (Phillips X'pert; MPD 3040, EA Almelo, The Netherlands). CuK $\alpha$ radiation $(\lambda=1.54430 \AA)$ was used to record the diffraction pattern of gold nanoparticles in $2 \theta$ range of $20-80$ degrees $\left(^{\circ}\right)$ [28]. The average particle size of gold nanoparticles was obtained using Debye-Scherrer's formula.

The size of nanoparticles and their size-distribution was characterized using DynaProTC-04 dynamic light scattering (DLS) instrument attached to ZetaSizer (Malvern, UK). The colloidal aqueous solution of gold nanoparticles was sonicated for $20 \mathrm{~min}$ before DLS measurements.

For transmission electron microscopy, $10 \mu \mathrm{L}$ colloidal solution of gold nanoparticles was placed on the grid TEM. The grid was then air-dried completely at room temperature. Finally, grid placed in transmission electron microscope for analysis. The size distribution of gold nanoparticles was obtained by measuring the size of nanoparticles. The TEM analysis was carried out using JOEL-2100 (Tokyo, Japan) at University Sophisticated Instrumentation Facility (USIF), AMU, Aligarh, India.

\subsection{Evaluation of Minimum Inhibitory Concentration (MIC)}

Listeria monocytogenes ATCC 19,114 and Serratia marcescens ATCC 13,880 were used in the present investigation to assess the antibacterial and antibiofilm activity of the synthesized AuNPs. Antibacterial potential of AuNPs was assessed in terms of MIC using the standard microbroth dilution method described previously [29].

\subsection{Biofilm Inhibition Activity}

Polystyrene microtiter plate assay using crystal violet as the staining dye was employed to determine the biofilm inhibitory potential of synthesized AuNPs at sub-MICs (0.06-0.5× MICs) against L. monocytogenes and S. marcescens [30].

\subsection{Extraction and Quantification of Exopolysaccharides (EPS)}

Effect of sub-MICs of AuNPs on EPS was determined by quantifying the total carbohydrate content of the bacterial cells as described previously [31]. The group without AuNPs treatment was considered as the control set. 


\subsection{Swarming Motility Assay}

Swarming behavior of test bacteria was assayed by point inoculating the overnight grown cultures on $0.5 \%$ Luria Bertani (LB) soft agar plates amended with sub-MICs of AuNPs. Inoculated plates were incubated for $24 \mathrm{~h}$ and diameter of the swarm was recorded post incubation [32].

\subsection{MATH Assay}

Cell surface hydrophobicity ( $\mathrm{CSH}$ ) is the measure of the ability of the bacteria to adhere to the substratum. Therefore, $\mathrm{CSH}$ of treated and untreated S. marcescens and L. monocytogenes was determined using microbial adhesion to hydrocarbon (MATH) assay [33]. Briefly, bacteria were added to tubes containing $3 \mathrm{~mL}$ of LB broth with or without subinhibitory concentrations of AuNPs and left for incubation for $24 \mathrm{~h}$. Hydrocarbon (toluene) was added to the tubes and vortexed vigorously for $180 \mathrm{~s}$. Tubes were left undisturbed for $10 \mathrm{~min}$ to separate out the phases, lower aqueous phase was collected and absorbance was read at $600 \mathrm{~nm}$ before and after vortexing.

\subsection{Disruption of Mature (Preformed) Biofilm}

One day ( $24 \mathrm{~h}$ ) old biofilms of $S$. marcescens and L. monocytogenes formed in 96-well microtiter plate was treated with sub-MICs of AuNPs and again incubated for $24 \mathrm{~h} \mathrm{du}-$ ration. After incubation, growth media was removed from wells and adhered cells were washed thrice, stained with crystal violet, and absorbance was read at $585 \mathrm{~nm}$ to assess the disruption of preformed biofilm [34].

\subsection{ROS Generation}

Levels of ROS generated in cells of test pathogen upon treatment with AuNPs was evaluated using a fluorescent probe 2,7-dichlorofluorescein diacetate (DCHF-DA) as described previously [35].

\subsection{Cell Viability Assay/MTT Assay}

3-(4, 5-dimethylthiazol-2-yl)-2, 5-diphenyl tetrazoliumbromide protocol was performed to show the effect of TA-AuNPs on the viability of HepG2 cell lines. The cells were seeded $\left(1 \times 10^{4}\right.$ cells per well $)$ in $1 \mathrm{~mL}$ of culture medium consisting of $10-200 \mu \mathrm{g} / \mathrm{mL}$ dilution of TA-AuNPs in 24-well microtiter plates. Cells were kept in a humidified incubator for $48 \mathrm{~h}$ at $37^{\circ} \mathrm{C}, 200 \mu \mathrm{L}$ of 3-94,5-dimethylthiazol-2-yl)-2,5-diphenyl tetrazoliumbromide ( $5 \mathrm{mg} / \mathrm{mL}$ phosphate buffer saline, PBS) was supplemented to each well and kept for $2 \mathrm{~h}$, $200 \mu \mathrm{L}$ of DMSO was added to each plate which was then spun $(1800 \times g$ for $5 \mathrm{~min}$ at $4{ }^{\circ} \mathrm{C}$ ). The readings at $540 \mathrm{~nm}$ wavelength were noted on a microplate reader (Elx 800). Effect of TA-AuNPs on inhibition of growth was calculated as \% cell viability as DMSOadministrated cells were retained as control. Absorbance numbers of media containing wells were subtracted from test sample values.

$$
\% \text { Cell viability }=\frac{\text { Absorbance of sample }- \text { absorbance of blank }}{\text { Absorbance of DMSO }- \text { absorbance of blank }} \times 100
$$

\subsection{Protein Determination (Bradford Assay)}

Bradford assay was employed for determination of protein content from cell pellets obtained from HepG2 cancer cells treated with TA-AuNPs [36].

\subsection{Measurement of GSH Levels in HepG2 Cancer Cell LINES}

HepG2 cancer cells treated with TA-AuNPs were centrifuged and cellular protein was precipitated. Consequently, $0.4 \mathrm{M},(\mathrm{pH}-8.9)$ Tris buffer and DTNB were added to the supernatant consecutively and incubated for $10 \mathrm{~min}$ on shaking at $37^{\circ} \mathrm{C}$. Color intensity was measured at $412 \mathrm{~nm}$ [37]. 


\subsection{Estimation of Lipid Peroxidation in HepG2 Cancer Cell Lines}

TBARS assay was used for estimation of lipid peroxidation (LPO). TA-AuNPs administrated HepG2 cells were centrifuged, sonicated, and then again centrifuged. Supernatant was collected and $1 \mathrm{~mL}$ of thiobarbituric acid (TBA) was added to $500 \mu \mathrm{L}$ of supernatant and incubated for $15 \mathrm{~min}$ at $100{ }^{\circ} \mathrm{C}$ in water bath. The reaction mixture was allowed to cool before cell centrifugation at $13,000 \times g$ for $2 \mathrm{~min}$. A total of $500 \mu \mathrm{L}$ of lysate supernatant was removed and fluorescent adduct was measured at $550 \mathrm{~nm}$. TBARS are expressed as MDA equivalents [38].

\section{Results and Discussion}

\subsection{Synthesis and Characterization of AuNPs}

In this study, a green route for the synthesis of gold nanoparticles was adopted. The phytocompounds present in the aqueous extract of Trachyspermum ammi seeds acted as reducing agent and capping agent for the synthesis. The microwave irradiation was used to accelerate the reaction process and to obtain the controlled size of AuNPs [27]. Initially, the color of $\mathrm{HAuCl}_{4}$ solution was light yellow that changed to ruby red after microwave irradiation. This change in color is due to the reduction of $\mathrm{Au}^{3+}$ and formation of gold nanoparticles [39]. The UV-vis spectrum of gold nanoparticles is presented in Figure 1A. The aqueous extract of Trachyspermum ammi seeds do not exhibit any prominent absorption band in the range of 400-700 $\mathrm{nm}$ [40]. The microwave irradiation of mixture of T. ammi extract and $\mathrm{HAuCl}_{4}$ caused the change of reaction mixture to ruby red indicating the formation of gold nanoparticles. The synthesis of gold nanoparticles is also evident from the UV-vis absorption spectrum. A broad band was recorded in $550-600 \mathrm{~nm}$ range which is indicative of the polydisperse nature of gold nanoparticles [41]. This absorption band is attributed to the SPR of the gold nanoparticles. Moreover, the finding is agreement with an earlier report where gold nanoparticles synthesized using olibanum gum exhibited SPR near $530 \mathrm{~nm}[27,42]$. The compounds present in the extract of T. ammi acted as reducing and capping agents and are responsible for the reduction of $\mathrm{Au}^{+3}$ and synthesis of gold nanoparticles.
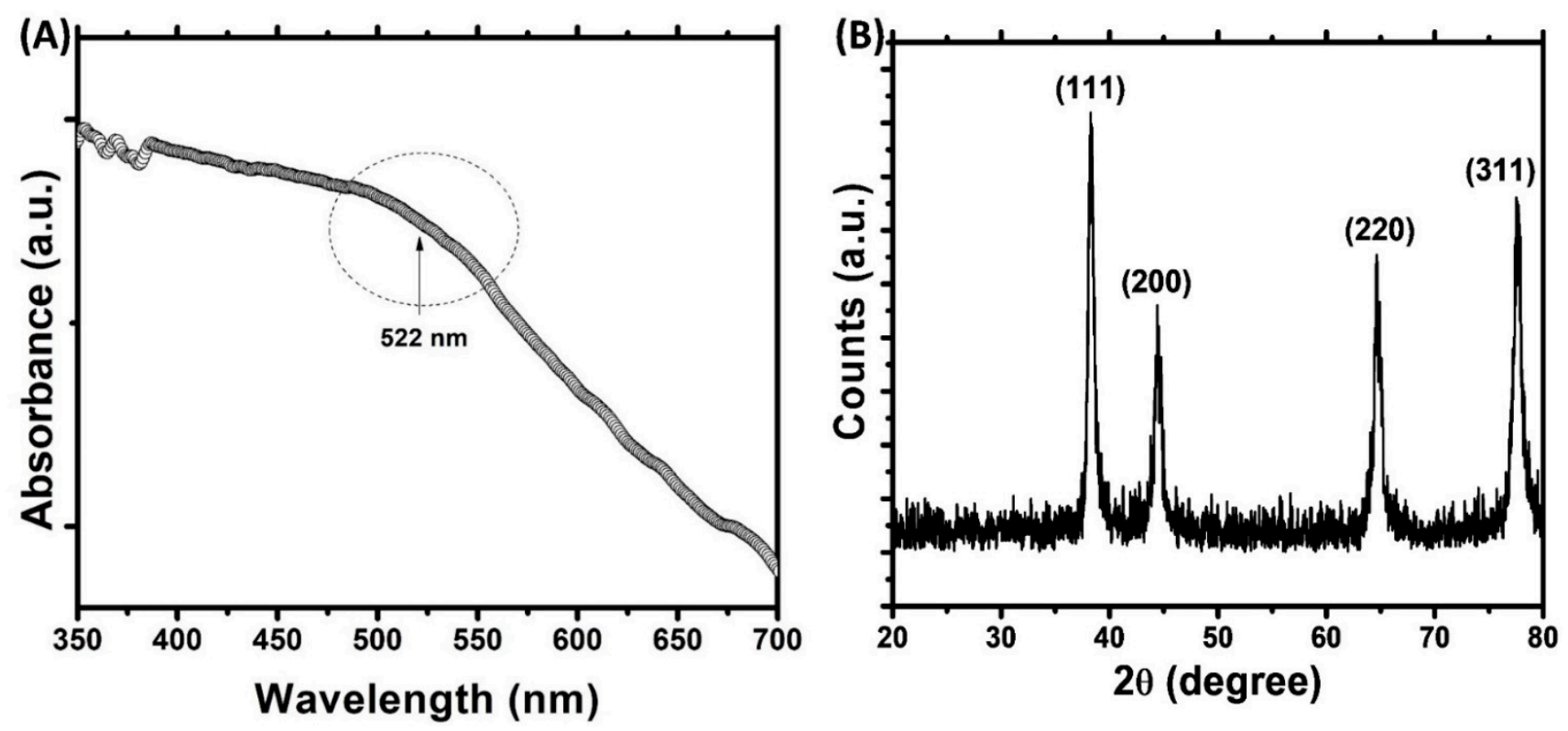

Figure 1. (A) UV-visible absorption spectrum of gold nanoparticles. Arbitrary unit (a. u.) (B) X-ray diffraction (XRD) pattern of gold nanoparticles. 
The FTIR spectrum of aqueous seed extract of T. ammi has been reported earlier that exhibited peaks at 2927,1607,1405, 1076, $617 \mathrm{~cm}^{-1}$ [40]. These peaks are due to the presence of soluble organic components of the extract which may be responsible for the synthesis of gold nanoparticles. Moreover, it is envisaged that presence of polyphenols such as thymol (major phytoconstituent of T. ammi) were responsible for bioreduction and capping process.

The presence of crystalline gold nanoparticles was confirmed by XRD analysis. The XRD pattern of gold nanoparticles is shown in Figure 1B. The presence of four diffraction peaks at $38.28,44.42,64.66$, and $77.50^{\circ}$ were observed. These peaks correspond to (111), (200), (220), and (311) sets of lattice planes that are indexed to face-centered cubic (fcc) crystal structure (JCPDS No. 04-0784). The absence of other diffraction peaks indicates that AuNPs were of pure crystalline. The nanoparticle size was calculated using DebyeScherrer's Equation (1) [33]:

$$
D_{p}=\frac{0.9 \lambda}{\beta \cos \theta}
$$

$D p$ is crystalline size; $\lambda$ is wavelength of $C u K \alpha(1.54060 \AA) ; \theta$ is Bragg angle; $\beta$ is full width at half maxima (FWHM). The average crystalline size of gold nanoparticles was found to be $16.63 \mathrm{~nm}$.

Transmission electron microscopic (TEM) analyses of gold nanoparticles were performed to obtain the shape and size distribution of the particles. Transmission electron micrograph of gold nanoparticles is shown in Figure 2A. As evident from the figure, most nanoparticles were observed as spherical and spheroidal with few anisotropies. The size of particles ranged from 3 to $23 \mathrm{~nm}$ (Figure 2B). The average particle size using TEM analysis was found to be $11.11 \mathrm{~nm}$. The size of green synthesized nanoparticles as well as their size distribution depends on relative nucleation rate and the extent of agglomeration [43]. The average range of the gold nanoparticles was similar to an earlier report in which gold nanoparticles synthesized using aqueous extract of Garcinia mangostana fruit were found to be $16 \mathrm{~nm}$ using XRD data [44]. Dynamic light scattering (DLS) measurements were carried out to further validate the size of nanoparticles. The average diameter of gold nanoparticles using DLS were found to be $24.4 \mathrm{~nm}$ (Figure 3).
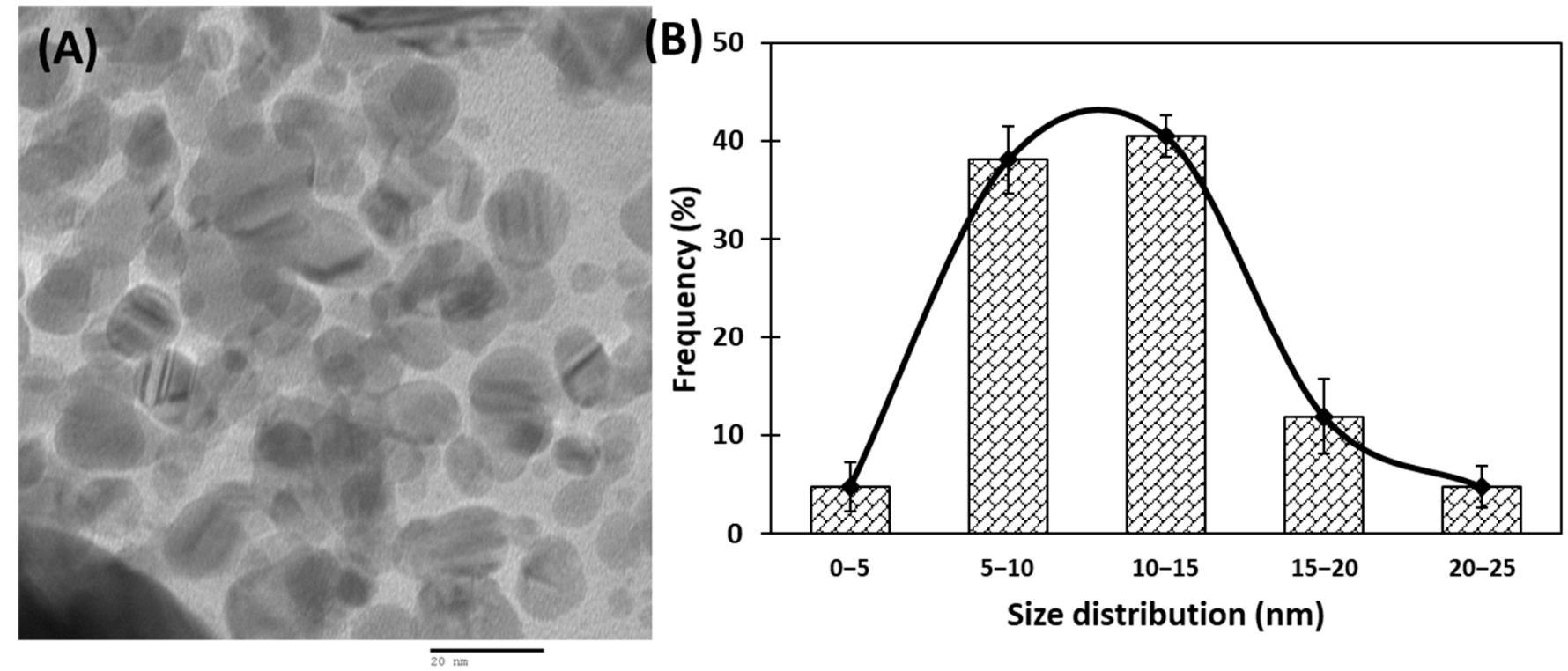

Figure 2. (A) Transmission electron microscopic (TEM) image of gold nanoparticles at 200,000 $\times$ and $200 \mathrm{kV}$. (B) Frequency of gold nanoparticles size distribution. 


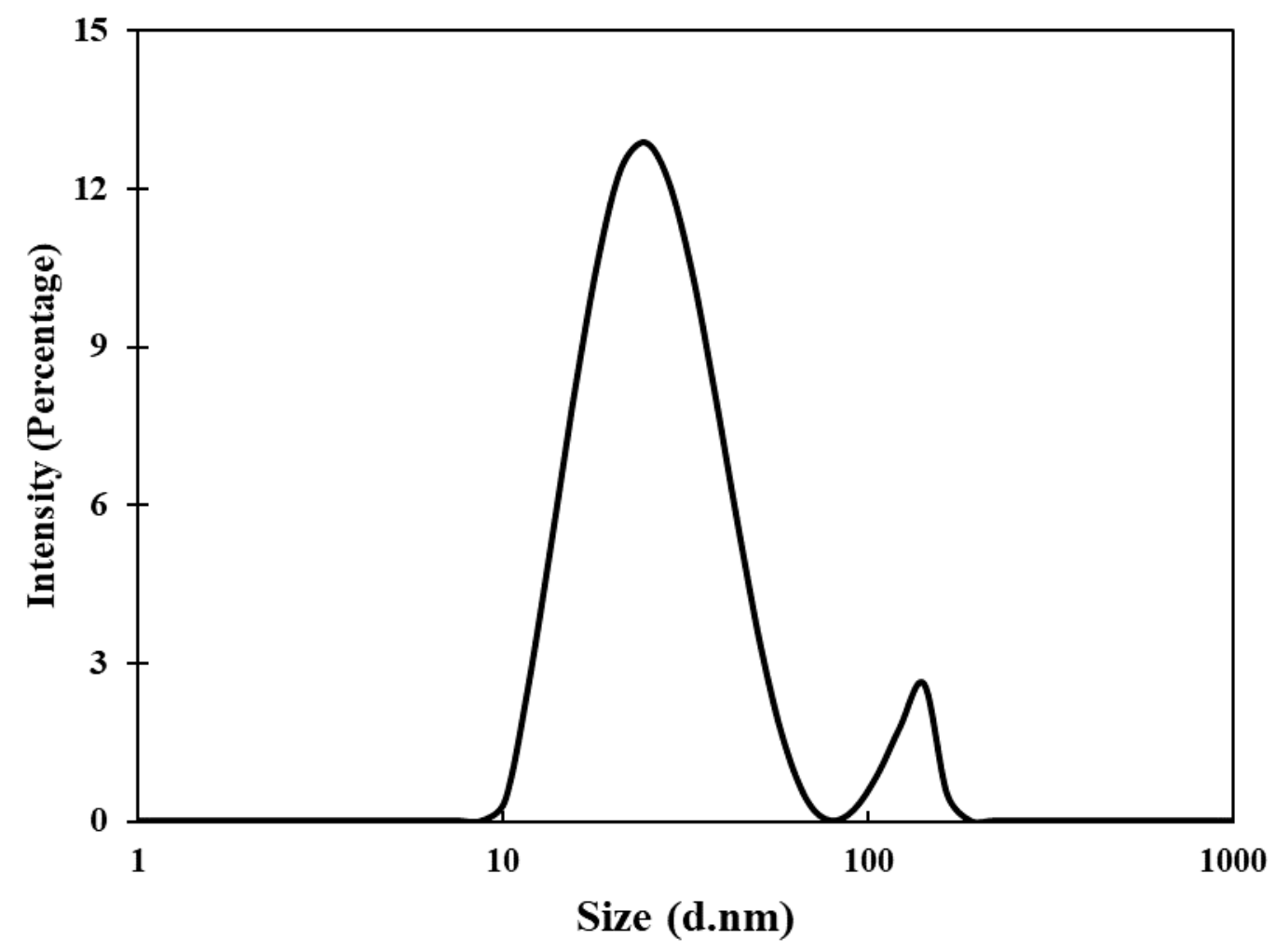

Figure 3. Hydrodynamic diameter of gold nanoparticles using dynamic light scattering (DLS) measurements.

\subsection{Minimum Inhibitory Concentration (MIC)}

Lowest concentration at which no visible growth is observed is termed as the MIC. In the present investigation, two food associated bacteria (S. marcescens and Listeria monocytogenes) were evaluated using the AuNPs fabricated from the seed extract of T. ammi (TA-AuNPs). Synthesized TA-AuNPs demonstrated MICs of 16 and $32 \mu \mathrm{g} / \mathrm{mL}$ against $S$. marcescens and Listeria monocytogenes, respectively. Higher MIC value exhibited by Gram positive L. monocytogenes in comparison to the S. marcescens (Gram negative) could be attributed to the difference in the structure and constitution of the cell wall. The cell wall of the Gram-positive bacteria is made of a thick layer of peptidoglycan with covalently attached teichuronic and teichoic acid making them less susceptible to the action of NPs [42,45]. Concentrations below MIC i.e., sub-MICs were considered for biofilm and virulence assays.

\subsection{Biofilm Inhibition Studies}

Aggregation of free-living planktonic bacteria through several physiological factors like motility, cell attachment, proliferation, differentiation, and accumulation of multilayered cell aggregates in a polymeric matrix leads to the formation of biofilm [32]. A plethora of research findings have demonstrated that the matrix acts as a barrier and protects the cells against the action of antibiotics, detergents, disinfectants, and host immune responses making them resistant [46]. Therefore, control of biofilm is of paramount importance. The results of the efficacy of TA-AuNPs in inhibiting the biofilm formation of S. marcescens and Listeria monocytogenes are depicted in Figure 4A. Concentration dependent biofilm inhibition by TA-AuNPs was observed against both foodborne pathogens. Maximum reduction of $81 \%$ and $73 \%$ in the biofilm formation was recorded at $0.5 \times$ MIC against $S$. marcescens and Listeria monocytogenes, respectively. Further, statistically significant $(p \leq 0.05)$ biofilm inhibitory activity of TA-AuNPs recorded at lower sub-MICs $(0.062-0.25 \times$ MIC) against both the test pathogens is depicted in Figure 4A. Our observations corroborate well with findings on AuNPs fabricated using rhizome extract of Rhodiola rosea [47]. Synthesized AuNPs demonstrated significant biofilm inhibitory activity against E. coli and P. aeruginosa 
at sub-MICs. Further, in situ microscopic analysis was done using CLSM (Figure 4B) to validate the findings of the biofilm inhibition assay. Biofilms that were grown without TA-AuNPs treatment (control), exhibited highly multilayered aggregation of cells enclosed in an envelope of polymeric substances. On the contrary, treated cells of $S$. marcescens and L. monocytogenes were devoid of the characteristic biofilm architecture, scattered and disintegrated microcolonies were observed. Therefore, it is envisaged that the synthesized TA-AuNPs impedes biofilm formation in both S. marcescens and L. monocytogenes at sub-MICs.
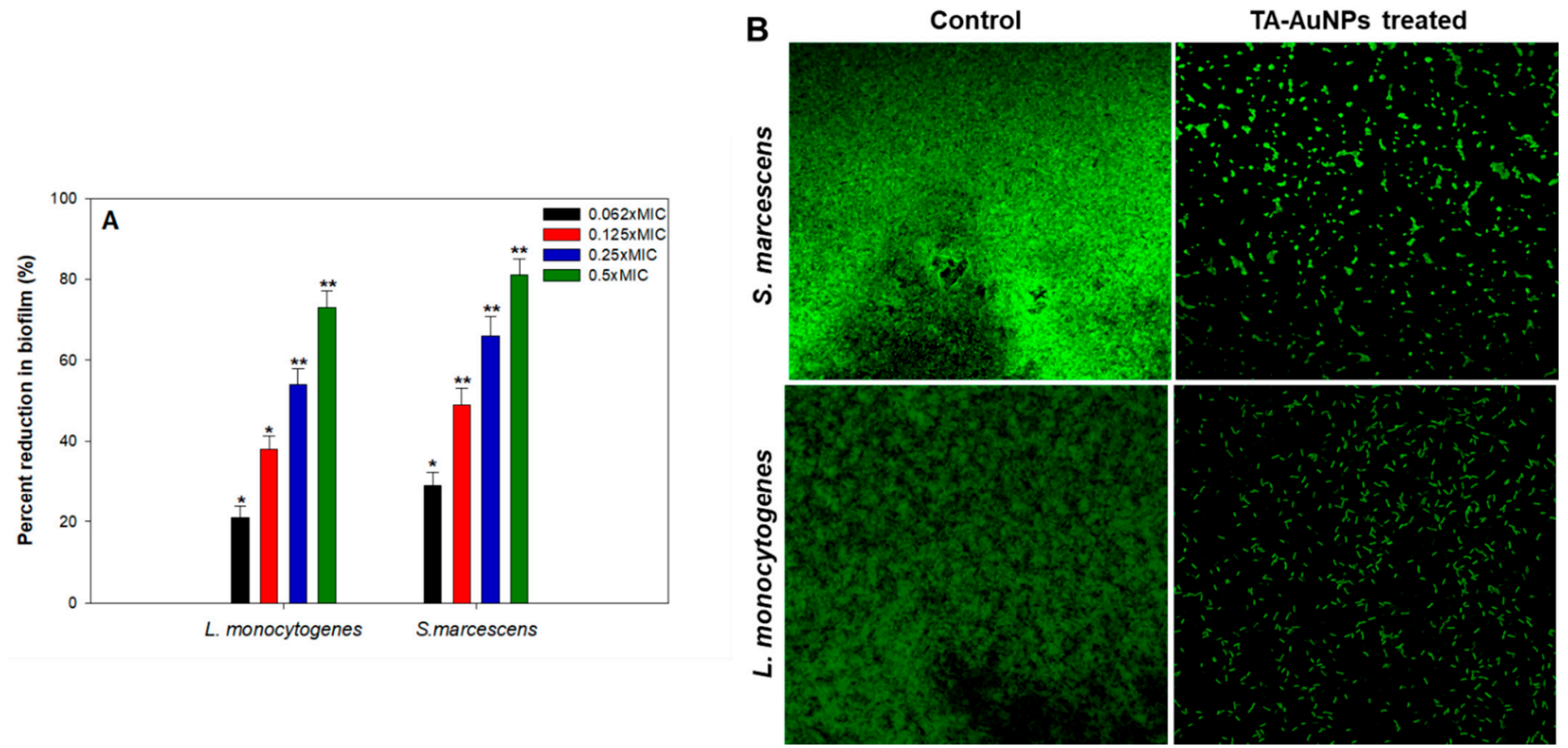

Figure 4. (A) Effect of sub-MICs of TA-AuNPs on biofilm formation. * denotes significance at $p \leq 0.05$ and ${ }^{* *}$ denotes significance at $p \leq 0.005$. (B) Confocal laser scanning microscopic images of L. monocytogenes and S. marcescens biofilm in the absence and presence of $0.5 \times$ MICs of TA-AuNPs.

\subsection{Effect of Sub-MICs of TA-AuNPs Biofilm Related Virulence Traits EPS}

Exopolysaccharides (EPS) are an important constituent of the bacterial biofilm as they have a vital role in the maintenance of the $3 \mathrm{D}$ biofilm architecture and providing resistance against the action of antimicrobials and immune responses [48]. Several studies have highlighted that interference with EPS production leads to disturbed biofilm architecture and eventually reduces the development of resistance against antimicrobials [49-51]. In light of this, TA-AuNPs were evaluated for their ability to inhibit EPS production in $S$. marcescens as well as L. monocytogenes. EPS was reduced significantly in both the test pathogens in the presence of respective sub-MICs (Figure 5A). There was $83 \%$ and $87 \%$ reduction in the presence of $0.5 \times$ MICs of TA-AuNPs, respectively. In S. marcescens, $26 \%, 36 \%$, and $67 \%$ impaired EPS production was recorded at $0.06 \times$ MIC, $0.125 \times$ MIC, and $0.25 \times$ MIC, respectively. Similar concentration dependent effect of TA-AuNPs was observed in L. monocytogenes, at concentrations ranging from $0.06 \times$ MIC to $0.25 \times$ MIC, $30-65 \%$ decrease in EPS was recorded. Our findings stand on par with the results reported with iron oxide nanoparticles, wherein, the nanoparticles reduced EPS production in $S$. marcescens, E. coli, P. aeruginosa, and L. monocytogenes by $15-80 \%$ at concentrations ranging from 2 to $16 \mu \mathrm{g} / \mathrm{mL}$ [52]. 


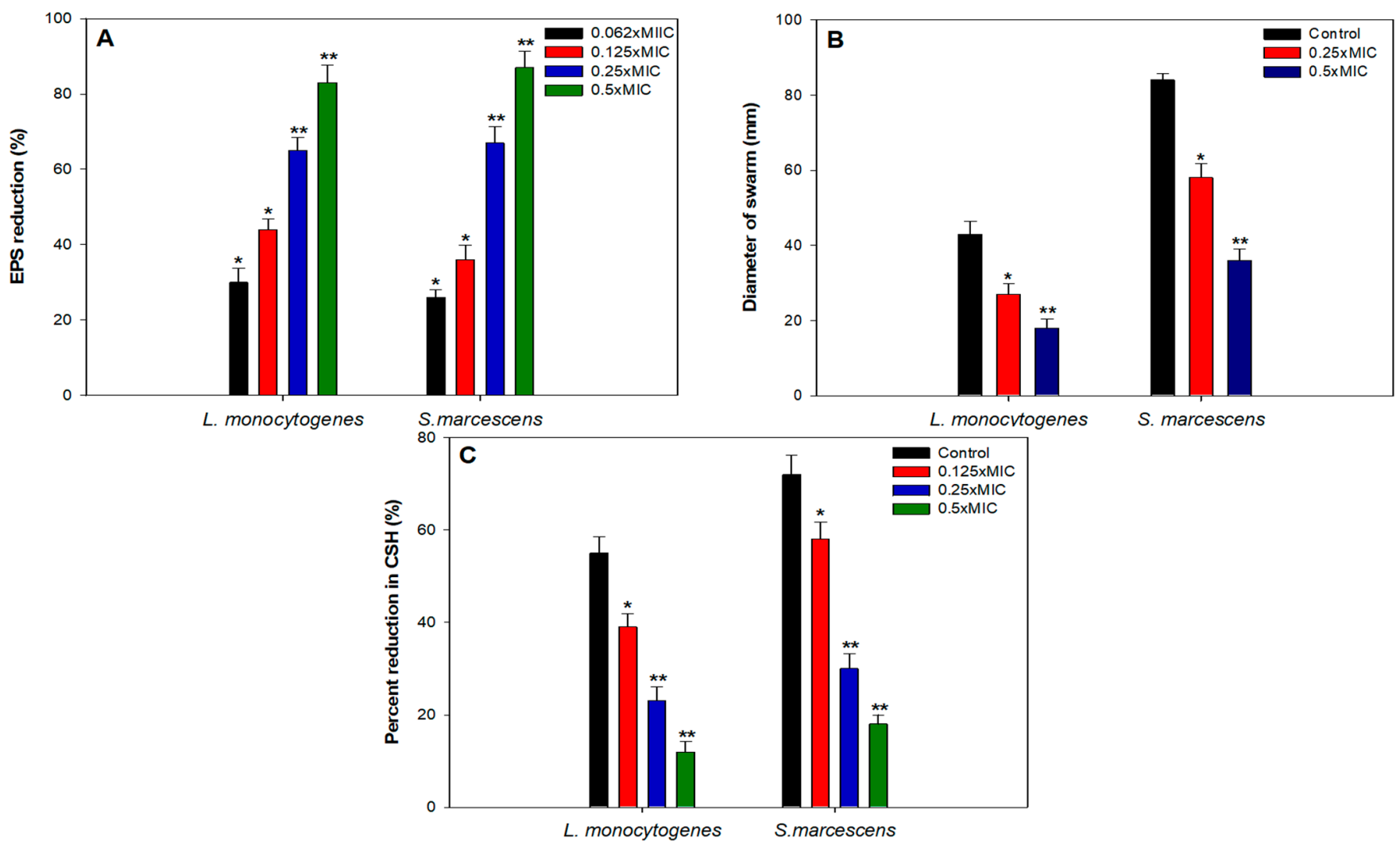

Figure 5. Effect of sub-MICs of TA-AuNPs on (A) EPS, (B) swarming motility, (C) cell surface hydrophobicity in L. monocytogenes and S. marcescens. Data are represented as mean values of triplicate readings and bar is standard deviation. * denotes significance at $p \leq 0.05$, and ${ }^{* *}$ denotes significance at $p \leq 0.005$.

\subsection{Swarming Motility}

Initial attachment of cells to biotic or abiotic surfaces is crucial to biofilm development. Bacteria utilize flagellar driven swarming motility to adhere initially to the substratum. In both L. monocytogenes and S. marcescens, flagellar-driven motility is known to play a pivotal role in the initial attachment and subsequent biofilm formation [32,53-55]. Any intervention in the motility of the bacteria is bound to impact the attachment process negatively and eventually lead to impaired biofilm formation. In this regard, sub-MICs $(0.06-0.5 \times$ MIC) of TA-AuNPs were examined for their efficacy in reducing swarming motility. Figure 5B depicts the concentration dependent suppression of motility in the L. monocytogenes and $S$. marcescens. Highest decrease of $58 \%$ and $64 \%$ in the swarming behavior of L. monocytogenes and S. marcescens respectively, was recorded as compared to their untreated controls. Our results find support from the observations made with sub-MICs of AgNPs, ZnO nanoparticles and $\mathrm{ZnO}$-xanthan gum nanocomposite, wherein a significant drop in the swarming motility behavior was recorded in test pathogens [49,56-58].

\subsection{Cell Surface Hydrophobicity (CSH)}

Hydrophobicity index is the measure of the charge carried by the cell surface, it is one of the key elements that facilitates the process of accumulation, aggregation, and attachment of cells. In view of this, it is envisaged that by reducing the hydrophobicity index of the cells, the accumulation and aggregation of the cells will be reduced and consequently impair biofilm formation [55]. Thus, we assessed the effect of sub-MICs of TA-AuNPs on the CSH of both S. marcescens and L. monocytogenes using MATH assay. Obtained data exhibited concentration dependent significant reduction in CSH as shown in Figure 5C. In case of S. marcescens, untreated control showed $72 \% \mathrm{CSH}$, while, treatment with 2,4 , and $8 \mu \mathrm{g} / \mathrm{mL}$ resulted in $58 \%, 30 \%$, and $18 \% \mathrm{CSH}$. Similarly, L. monocytogenes also demonstrated 
decreased CSH ranging from $39 \%$ to $12 \%$ upon treatment with $0.125-0.5 \times$ MIC of TAAuNPs. This drop in the hydrophobicity of test pathogens could plausibly be one of the reasons for the biofilm impediment observed in the earlier assays. Data obtained agrees with the findings on zinc oxide-xanthan gum nanocomposite wherein, only $21 \%$ and $16 \%$ CSH was recorded in C. violaceum and S. marcescens upon treatment with $0.5 \times$ MICs [58]. In another study conducted on P. aeruginosa biofilm using $\mathrm{Cu}$ nanoparticles, reduced biofilm formation in P. aeruginosa was attributed to the decreased CSH [59].

\subsection{Effect on Preformed Biofilms}

Bacterial cells residing in the biofilm mode can tolerate multiple stress conditions and are almost 1000 times more resistant to bactericidal agents as well [60]. Thus, the disruption of preformed mature biofilm is rather difficult and hence, we evaluated the ability of TA-AuNPs to obliterate mature biofilms of S. marcescens and L. monocytogenes. The results clearly demonstrated a significant level of biofilm disruption in the test pathogens at tested sub-MICs of TA-AuNPs (Figure 6). In S. marcescens, preformed biofilm was reduced by $21 \%, 36 \%$, and $64 \%$ upon treatment with 2,4 , and $8 \mu \mathrm{g} / \mathrm{mL}$ concentration of TA-AuNPs. Preformed biofilms of L. monocytogenes witnessed a drop of $17-58 \%$ over untreated control at concentrations ranging from 4 to $16 \mu \mathrm{g} / \mathrm{mL}(0.125-0.5 \times \mathrm{MIC})$. Mature biofilm possesses a robust EPS matrix that resists the action of antimicrobials and host immune response. Our results indicate that the synthesized AuNPs interfere with the EPS matrix, disintegrate the architecture of the biofilm, and make the cells susceptible to antibiotics. Nanocomposite comprising AuNPs and reduced graphene oxide (Au-RGO) demonstrated similar concentration dependent obliteration of preformed mature biofilm of L. monocytogenes, MRSA, S. marcescens, E. coli, and P. aeruginosa at concentration ranging from 0.25 to $0.5 \times$ MICs [61]. Our results are in accordance with those reported with the Au-RGO.

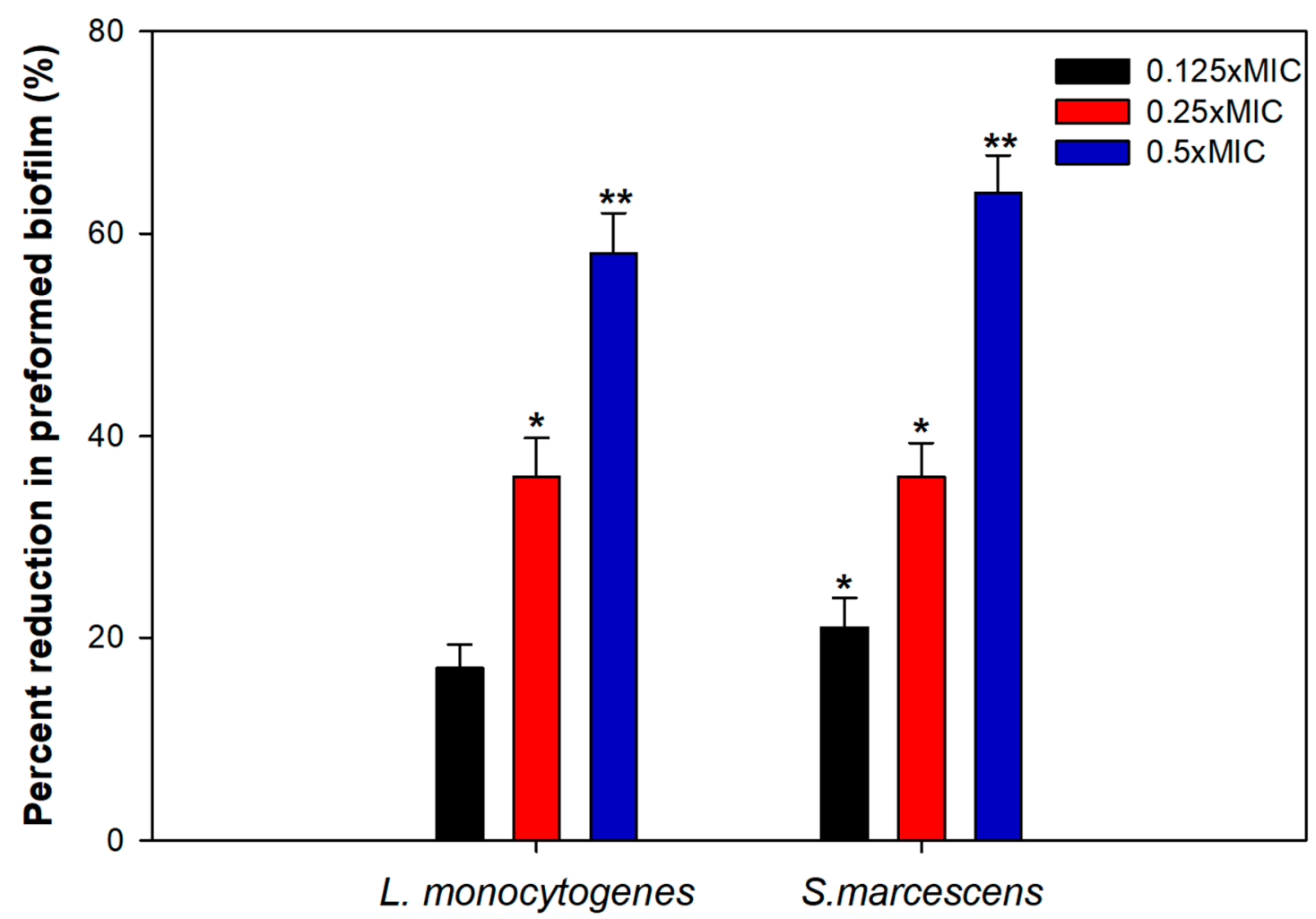

Figure 6. Disruption of preformed biofilm by sub-MICs of TA-AuNPs. * denotes significance at $p \leq 0.05,{ }^{* *}$ denotes significance at $p \leq 0.005$. 


\subsection{Mechanism of Biofilm Inhibition}

Effect of highest tested sub-MIC $(0.5 \times$ MIC) of TA-AuNPs on the growth of $S$. marcescens and L. monocytogenes was assessed and no significant reduction in the viability of the bacteria was observed (data not shown). Thus, the reduction in biofilm upon treatment with sub-MICs of TA-AuNPs is plausibly not due to the killing of the bacterial cells.

To uncover the plausible mechanism of biofilm inhibition, intracellular ROS generation in TA-AuNPs treated cells was evaluated. Considerably elevated ROS levels were observed in cells of S. marcescens and L. monocytogenes treated with 0.25-0.5 $\times$ MICs of the AuNPs (Figure 7). Intracellular ROS production increased by $59 \%$ and $51 \%$ in L. monocytogenes and S. marcescens, respectively, treated with $0.5 \times$ MICs of AuNPs. Increased ROS production is one of the most important mechanisms through which AuNPs disrupt the normal functioning of bacterial cells. Thus, it is envisaged that the interaction between bacterial cells and synthesized AuNPs induces higher ROS production due to metabolic imbalance in the cells. Increased ROS levels overpower the antioxidant defense system of the cells leading to oxidative stress, initiating lipid peroxidation, cell membrane damage, and finally cell death [62]. Our study elucidates that the TA-AuNPs induces an upsurge in the production of intracellular ROS in L. monocytogenes and S. marcescens that exceeds the capacity of antioxidant system of the cells and leads to cell death.

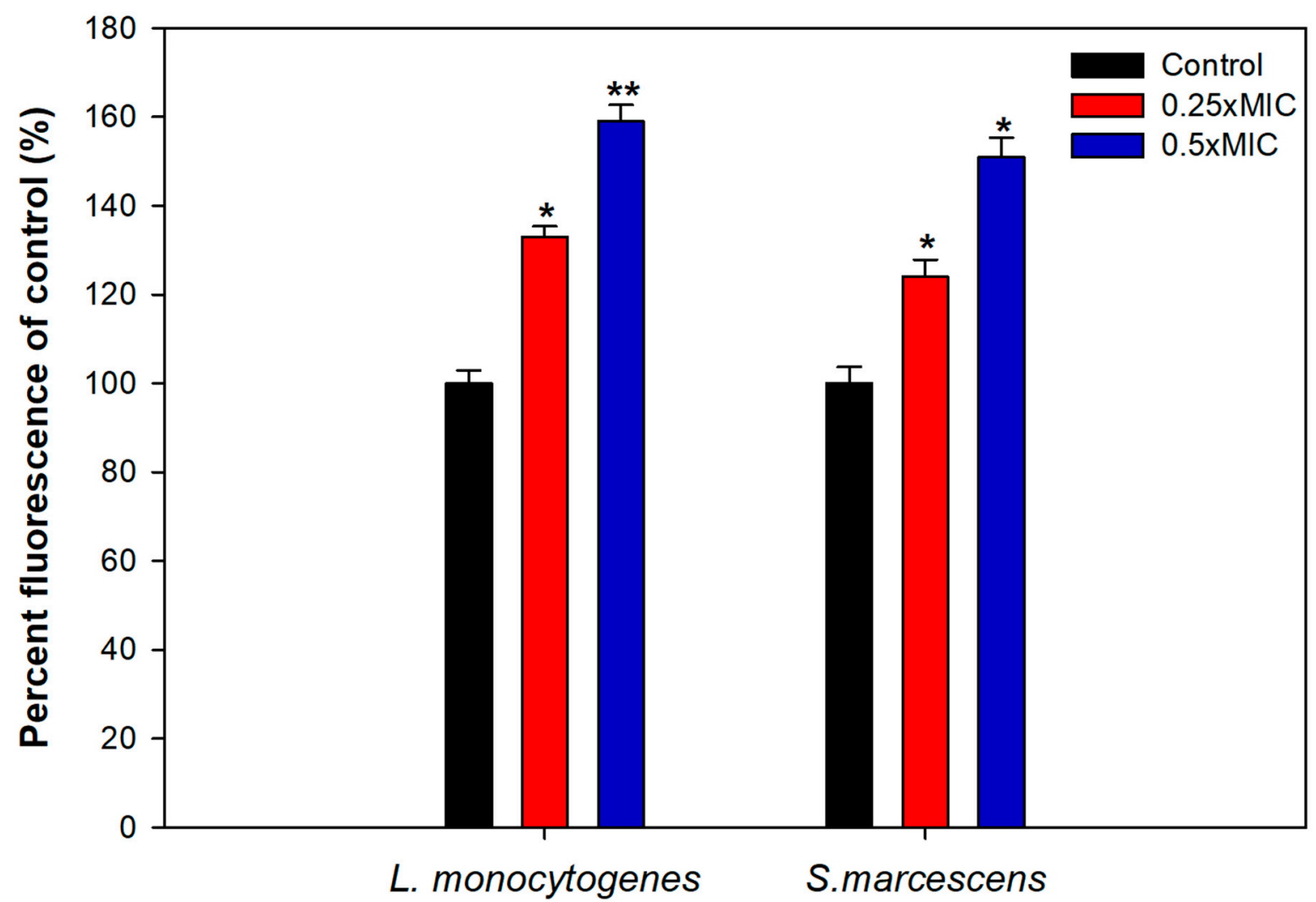

Figure 7. Intracellular ROS generation induced in test bacterial pathogens treated with sub-MICs of TA-AuNPs. * denotes significance at $p \leq 0.05,{ }^{* *}$ denotes significance at $p \leq 0.005$.

\section{TA-AuNPs Inhibits Growth and Viability of HepG2 Cancer Cells}

To scrutinize the antiproliferative prospective of TA-AuNPs, we executed 3-(4, 5dimethythiazol-2-yl)-2, 5-diphenyl tetrazolium bromide (MTT) assay against HepG2 cancer cells. It was observed that TA-AuNPs administration $(0-100 \mu \mathrm{M}$ for 24 and $48 \mathrm{~h})$ to HepG2 cells results in inhibition of cell growth in a concentration and time-dependent approach. Time course scrutiny revealed HepG2 cells respond to TA-AuNPs treatment within $48 \mathrm{~h}$. 
The $\mathrm{IC}_{50}$ value of TA-AuNPs treated HepG2 was $92.453 \mu \mathrm{g} / \mathrm{mL}$. The data suggested that TA-AuNPs treatment showed a significant potential in inhibiting proliferation of HepG2 cells (Figure 8A). Cellular propagation consequential in tumor pattern might occur because of the alteration in cell cycle regulation. A crucial primary origin of cancer succession is recognized by speedy and candid proliferation results to series and expansion of tissue accrual $[63,64]$. Results of MTT assay specified that TA-AuNPs is certain in its activity and proficient against cell cancer cell lines from different derivation. Cell growth in HepG2 cells is transformed by TA-AuNPs. Administration of TA-AuNPs resulted in the arrest of cellular proliferation in a concentration-dependent manner; magnification in the hammering of cell viability was experiential with amplification in the concentration of dose.
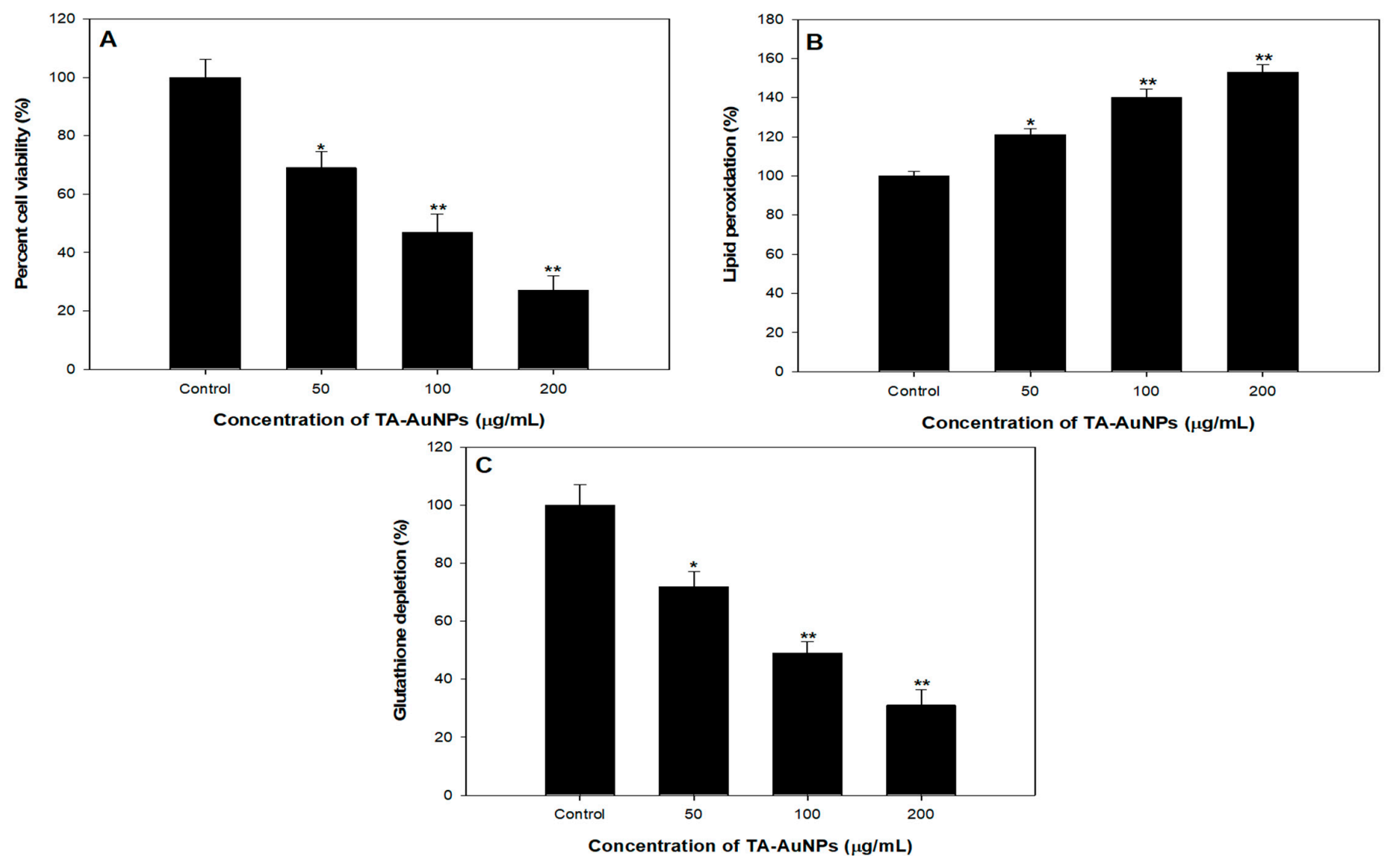

Figure 8. Anticancer studies against HepG2 cell lines. (A) Cytotoxicity assessment by MTT assay. (B) Effect on lipid peroxidation. (C) Percent change in glutathione levels. ${ }^{*} p<0.05,{ }^{* *} p<0.005$.

\section{Effect of TA-AuNPs Treatment on Lipid Peroxidation in HepG2 Cancer Cells}

Lipid peroxidation induced by reactive oxygen species (ROS) generation plays a crucial part in cell death including autophagy and apoptosis. This essential and preserved mechanism is based on an excessive production of ROS, which leads to impairment of bio membranes, encourages lipid peroxidation chain reactions, and consequently persuades cell death. We observed a dose dependent effect of TA-AuNPs on lipid peroxidation in HepG2 cancer cells. A noticeable increase in Lipid peroxidation with increase in concentration of TA-AuNPs (100 and $200 \mu \mathrm{g} / \mathrm{mL}$ ) treatment was seen in HepG2 cancer cell lines (Figure 8B). 


\section{TA-AuNPs Treatment Leads to Depletion of Intracellular Glutathione (GSH) of HepG2 Cancer Cells}

GSH redox is a vital element in most of the biological processes like regulation of cell-proliferation and apoptosis, control of various signal transduction pathways, initiation of genes at transcription level. Our results revealed that administration of TA-AuNPs significantly depleted the GSH levels in HepG2 cancer cells (Figure 8C), which signifies that TA-AuNPs may acts as potent anticancer therapy. At $200 \mu \mathrm{g} / \mathrm{mL}$, the statistically significant depletion of $75 \%$ in GSH levels was seen while at $100 \mu \mathrm{g} / \mathrm{mL}, 56 \%$ reduction in GSH levels was seen after treatment of TA-AuNPs in HepG2 cancer cells (Figure 8C). Redox status (one major component being GSH) is a major determinant of metastatic aggressiveness and sensitivity to chemotherapeutic agents. GSH deficit, or a reduction in the GSH/glutathione disulphide (GSSG) ratio, results in an amplified susceptibility to oxidative stress associated with the growth of cancer, raised GSH intensities increase the antioxidant capability and the resistance to oxidative stress as pragmatic in various types of cancer cells [65]. GSH is a documented marker of oxidative stress and leading scavenger of ROS. Our results support previous studies by decreasing the intracellular GSH in HepG2 cancer cell lines after treatment of TA-AuNPs. Therefore, posing cells become more prone to ROS generation, hence induce apoptosis. The overall results provide preliminary confirmation of the view that cellular GSH expression in cancer cells may be a target for therapeutic operations [66]. On the basis of our results, we propose that TA-AuNPs may act as an anticancer therapeutic agent.

\section{Conclusions}

The research work embodies a rapid microwave-assisted green synthesis method of gold nanoparticles using the seed extract of T. ammi as capping and reducing agent. Our data throws light on the biofilm inhibitory potential of the synthesized NPs at SUBMICs against pathogens, L. monocytogenes and S. marcescens. TA-AuNPs were found effective in thwarting virulence factors like EPS, swarming motility, and CSH that facilitates the formation and maintenance of biofilms. Further, the NPs not only inhibited biofilm formation but also disrupted robust preformed biofilms of the test pathogens. The study describes the enhanced ROS production as the plausible mechanism of antibiofilm action. Further, these NPs were found to be effective anticancer agents against HepG2 cancer cell lines. Thus, we can conclude that the synthesis route is environmentally friendly and the synthesized AuNPs possess significant antibiofilm and anticancer potential that can be exploited in various biomedical applications.

Author Contributions: Conceptualization: F.M.H., T.A. and S.R.; methodology, K.P., F.M.H., F.A.Q., A.K., P.A., T.A. and S.R.; software, F.M.H., F.A.Q., A.K., P.A.; validation, K.P., F.M.H., F.A.Q., A.K. and P.A.; formal analysis, F.M.H., F.A.Q., A.K., P.A., T.A. and S.R.; investigation, K.P., F.M.H., F.A.Q., A.K., P.A., T.A. and S.R.; resources, S.R., A.M.A. and M.M.A.A.; data curation, K.P., F.M.H., F.A.Q., T.A. and S.R.; writing—original draft preparation, K.P., F.M.H., F.A.Q., T.A. and S.R.; writing-review and editing, F.M.H., F.A.Q., A.K. and P.A.; visualization, F.A.Q., A.K. and P.A.; supervision, A.M.A. and M.M.A.A.; project administration, A.M.A. and M.M.A.A.; funding acquisition, S.R. All authors have read and agreed to the published version of the manuscript.

Funding: This research received no external funding.

Institutional Review Board Statement: Not applicable.

Informed Consent Statement: Not applicable.

Data Availability Statement: The data presented in this study are available on request from the corresponding author.

Acknowledgments: Authors are grateful to the Deanship of Scientific Research at King Saud University for its funding of this research through Research Group number RGP-193.

Conflicts of Interest: The authors declare no conflict of interest. 


\section{References}

1. Andujar, B.C.; Tung, L.D.; Thanh, N.T.K. Synthesis of nanoparticles for biomedical applications. Annu. Rep. Sect. A Inorg. Chem. 2010, 106, 553. [CrossRef]

2. Qamar, S.A.; Asgher, M.; Khalid, N.; Sadaf, M. Nanobiotechnology in health sciences: Current applications and future perspectives. Biocatal. Agric. Biotechnol. 2019, 22. [CrossRef]

3. Kubik, B.K.; Sugisaka, M. From molecular biology to nanotechnology and nanomedicine. Biosystems 2002, 65, 123-138. [CrossRef]

4. Qais, F.A.; Samreen; Ahmad, I. Green Synthesis of Metal Nanoparticles: Characterization and their Antibacterial Efficacy. In Antibacterial Drug Discovery to Combat MDR; Springer: Singapore, 2019; pp. 635-680.

5. Zhang, D.; Ma, X.; Gu, Y.; Huang, H.; Zhang, G. Green Synthesis of Metallic Nanoparticles and Their Potential Applications to Treat Cancer. Front. Chem. 2020, 8. [CrossRef]

6. Joerger, R.; Klaus, T.; Granqvist, C.G. Biologically Produced Silver-Carbon Composite Materials for Optically Functional Thin-Film Coatings. Adv. Mater. 2000, 12, 407-409. [CrossRef]

7. Chauhan, R.P.; Charu, G.; Dhan, P. Methodological advancements in green nanotechnology and their applications in biological synthesis of herbal nanoparticles. Int. J. Bioassays 2012, 1, 6-10.

8. Ingale, A.G. Biogenic Synthesis of Nanoparticles and Potential Applications: An Eco-Friendly Approach. J. Nanomed. Nanotechnol. 2013, 04. [CrossRef]

9. Mukherjee, S.; Patra, C.R. Biologically synthesized metal nanoparticles: Recent advancement and future perspectives in cancer theranostics. Futur. Sci. OA 2017, 3, FSO203. [CrossRef]

10. Singh, J.; Dutta, T.; Kim, K.H.; Rawat, M.; Samddar, P.; Kumar, P. 'Green' synthesis of metals and their oxide nanoparticles: Applications for environmental remediation. J. Nanobiotechnology 2018, 16. [CrossRef]

11. Thanh, N.T.K.; Green, L.A.W. Functionalisation of nanoparticles for biomedical applications. Nano Today 2010, 5, 213-230. [CrossRef]

12. Rauwel, P.; Rauwel, E. Emerging Trends in Nanoparticle Synthesis Using Plant Extracts for Biomedical Applications. Glob. J. Nanomedicine 2017, 1, 555562. [CrossRef]

13. Husain, F.M.; Khan, M.S.; Siddiqui, S.; Khan, A.; Arshad, M.; Alyousef, A.A.; Rahman, M.; Al-Shabib, N.A.; Ahmad, I. Nanoparticles as new emerging antibacterials: Potentials and limitations. Antibact. Drug Discov. Combat MDR 2019, 561-579. [CrossRef]

14. Shakoor, S.; Mills, P.J.A.; Hasan, R. Antibiotic-Resistant Enteric Infections. Infect. Dis. Clin. N. Am. 2019, 33, 1105-1123. [CrossRef] [PubMed]

15. Andleeb, S.; Majid, M.; Sardar, S. Environmental and public health effects of antibiotics and AMR/ARGs. In Antibiotics and Antimicrobial Resistance Genes in the Environment; Elsevier: Amsterdam, The Netherlands, 2020; pp. $269-291$.

16. Lopez, D.; Vlamakis, H.; Kolter, R. Biofilms. Cold Spring Harb. Perspect. Biol. 2010, 2. [CrossRef]

17. Donlan, R.M. Biofilm Formation: A Clinically Relevant Microbiological Process. Clin. Infect. Dis. 2001, 33, 1387-1392. [CrossRef] [PubMed]

18. Schachter, B. Slimy business—the biotechnology of biofilms. Nat. Biotechnol. 2003, 21, 361-365. [CrossRef] [PubMed]

19. Martins, N.; Rodrigues, C.F. Biomaterial-Related Infections. J. Clin. Med. 2020, 9, 722. [CrossRef] [PubMed]

20. Lasa, I.; Pozo, J.L.; Penadés, J.R.; Leiva, J. Biofilms bacterianos e infección. An. Sist. Sanit. Navar. 2005, 28, 163-175. [CrossRef] [PubMed]

21. Farland, L.V. Normal flora: Diversity and functions. Microb. Ecol. Health Dis. 2000, 12, 193-207. [CrossRef]

22. Oliver, S.P.; Jayarao, B.M.; Almeida, R.A. Foodborne Pathogens in Milk and the Dairy Farm Environment: Food Safety and Public Health Implications. Foodborne Pathog. Dis. 2005, 2, 115-129. [CrossRef]

23. Raposo, A.; Pérez, E.; Faria, C.T.; Ferrús, M.A.; Carrascosa, C. Food Spoilage by Pseudomonas spp.-An Overview. In Foodborne Pathogens and Antibiotic Resistance; John Wiley \& Sons, Inc.: Hoboken, NJ, USA, 2017; pp. 41-71.

24. Gram, L.; Ravn, L.; Rasch, M.; Bruhn, J.B.; Christensen, A.B.; Givskov, M. Food spoilage-Interactions between food spoilage bacteria. Int. J. Food Microbiol. 2002, 78, 79-97. [CrossRef]

25. Priyanka, B.; Patil, R.; Dwarakanath, S. A review on detection methods used for foodborne pathogens. Indian J. Med. Res. 2016, 144, 327. [CrossRef]

26. Smith, J.; Fratamico, P.M.; Uhlich, G. Molecular mechanisms involved in biofilm formation by food-associated bacteria. In Biofilms in the Food and Beverage Industries; Elsevier: Cambridge, UK, 2009; pp. 42-98.

27. Assefa, G.A.; Mesfin, A.A.; Akele, L.M.; Alemu, K.A.; Gangapuram, B.R.; Guttena, V.; Alle, M. Microwave-Assisted Green Synthesis of Gold Nanoparticles Using Olibanum Gum (Boswellia serrate) and its Catalytic Reduction of 4-Nitrophenol and Hexacyanoferrate (III) by Sodium Borohydride. J. Clust. Sci. 2017, 28, 917-935. [CrossRef]

28. Qais, F.A.; Shafiq, A.; Khan, H.M.; Husain, F.M.; Khan, R.A.; Alenazi, B.; Alsalme, A.; Ahmad, I. Antibacterial effect of silver nanoparticles synthesized using Murraya koenigii (L.) against multidrug-resistant pathogens. Bioinorg. Chem. Appl. 2019, 2019. [CrossRef]

29. Husain, F.M.; Ansari, A.A.; Khan, A.; Ahmad, N.; Albadri, A.; Albalawi, T.H. Mitigation of acyl-homoserine lactone (AHL) based bacterial quorum sensing, virulence functions, and biofilm formation by yttrium oxide core/shell nanospheres: Novel approach to combat drug resistance. Sci. Rep. 2019, 9, 18476. [CrossRef]

30. Zubair, M.; Husain, F.M.; Qais, F.A.; Alam, P.; Ahmad, I.; Albalawi, T.; Ahmad, N.; Alam, M.; Baig, M.H.; Dong, J.J.; et al. Bio-fabrication of titanium oxide nanoparticles from Ochradenus arabicus to obliterate biofilms of drug-resistant Staphylococcus aureus and Pseudomonas aeruginosa isolated from diabetic foot infections. Appl. Nanosci. 2021. [CrossRef] 
31. Qais, F.A.; Khan, M.S.; Ahmad, I. Broad-spectrum quorum sensing and biofilm inhibition by green tea against gram-negative pathogenic bacteria: Deciphering the role of phytocompounds through molecular modelling. Microb. Pathog. 2019, 126, 379-392. [CrossRef] [PubMed]

32. Sivaranjani, M.; Gowrishankar, S.; Kamaladevi, A.; Pandian, S.K.; Balamurugan, K.; Ravi, A.V. Morin inhibits biofilm production and reduces the virulence of Listeria monocytogenes-An in vitro and in vivo approach. Int. J. Food Microbiol. 2016, 237, 73-82. [CrossRef]

33. Qais, F.A.; Shafiq, A.; Ahmad, I.; Husain, F.M.; Khan, R.A.; Hassan, I. Green synthesis of silver nanoparticles using Carum copticum: Assessment of its quorum sensing and biofilm inhibitory potential against gram negative bacterial pathogens. Microb. Pathog. 2020, 144. [CrossRef]

34. Hasan, I.; Qais, F.A.; Husain, F.M.; Khan, R.A.; Alsalme, A.; Alenazi, B.; Usman, M.; Jaafar, M.H.; Ahmad, I. Eco-friendly green synthesis of dextrin based poly (methyl methacrylate) grafted silver nanocomposites and their antibacterial and antibiofilm efficacy against multi-drug resistance pathogens. J. Clean. Prod. 2019, 230, 1148-1155. [CrossRef]

35. Qais, F.A.; Samreen; Ahmad, I. Broad-spectrum inhibitory effect of green synthesised silver nanoparticles from Withania somnifera (L.) on microbial growth, biofilm and respiration: A putative mechanistic approach. IET Nanobiotechnology 2018, 12, 325-335. [CrossRef]

36. Afsar, T.; Trembley, J.H.; Salomon, C.E.; Razak, S.; Khan, M.R.; Ahmed, K. Growth inhibition and apoptosis in cancer cells induced by polyphenolic compounds of Acacia hydaspica: Involvement of multiple signal transduction pathways. Sci. Rep. 2016, 6 . [CrossRef] [PubMed]

37. Okuno, S.; Sato, H.; Matsumura, K.K.; Tamba, M.; Wang, H.; Sohda, S.; Hamada, H.; Yoshikawa, H.; Kondo, T.; Bannai, S. Role of cystine transport in intracellular glutathione level and cisplatin resistance in human ovarian cancer cell lines. Br. J. Cancer 2003, 88, 951-956. [CrossRef] [PubMed]

38. Rao, T.N.; Riyazuddin; Babji, P.; Ahmad, N.; Khan, R.A.; Hassan, I.; Shahzad, S.A.; Husain, F.M. Green synthesis and structural classification of Acacia nilotica mediated-silver doped titanium oxide (Ag/TiO2) spherical nanoparticles: Assessment of its antimicrobial and anticancer activity. Saudi J. Biol. Sci. 2019, 26, 1385-1391. [CrossRef] [PubMed]

39. Rajkumari, J.; Busi, S.; Vasu, A.C.; Reddy, P. Facile green synthesis of baicalein fabricated gold nanoparticles and their antibiofilm activity against Pseudomonas aeruginosa PAO1. Microb. Pathog. 2017, 107, 261-269. [CrossRef] [PubMed]

40. Kaur, H.; Bhatnagar, A.; Tripathi, S.K. Size Tunable Green Synthesis of Silver Nanoparticles Using Trachyspermum Ammi (Ajwain) and Their Effect on a B Cell Line. J. Nanoeng. Nanomanufacturing 2013, 3, 154-161. [CrossRef]

41. Haiss, W.; Thanh, N.T.K.; Aveyard, J.; Fernig, D.G. Determination of Size and Concentration of Gold Nanoparticles from UV-Vis Spectra. Anal. Chem. 2007, 79, 4215-4221. [CrossRef]

42. Khan, S.A.; Shahid, S.; Lee, C.S. Green Synthesis of Gold and Silver Nanoparticles Using Leaf Extract of Clerodendrum inerme; Characterization, Antimicrobial, and Antioxidant Activities. Biomolecules 2020, 10, 835. [CrossRef]

43. Jeyaraj, M.; Varadan, S.; Anthony, K.J.P.; Murugan, M.; Raja, A.; Gurunathan, S. Antimicrobial and anticoagulation activity of silver nanoparticles synthesized from the culture supernatant of Pseudomonas aeruginosa. J. Ind. Eng. Chem. 2013, 19, 1299-1303. [CrossRef]

44. Lee, X.K.; Shameli, K.; Miyake, M.; Kuwano, N.; Khairudin, A.N.B.; Mohamad, S.E.; Yew, Y.P. Green Synthesis of Gold Nanoparticles Using Aqueous Extract of Garcinia mangostana Fruit Peels. J. Nanomater. 2016, 2016, 1-7. [CrossRef]

45. Slavin, Y.N.; Asnis, J.; Häfeli, U.O.; Bach, H. Metal nanoparticles: Understanding the mechanisms behind antibacterial activity. J. Nanobiotechnology 2017, 15, 65. [CrossRef] [PubMed]

46. Mah, T.F.C.; George, A.T. Mechanisms of biofilm resistance to antimicrobial agents. Trends Microbiol. 2001, 9, 34-39. [CrossRef]

47. Singh, P.; Pandit, S.; Beshay, M.; Mokkapati, V.R.S.S.; Garnaes, J.; Olsson, M.E.; Sultan, A.; Mackevica, A.; Mateiu, R.V.; Lütken, H.; et al. Anti-biofilm effects of gold and silver nanoparticles synthesized by the Rhodiola rosea rhizome extracts. Artif. Cells Nanomed. Biotechnol. 2018, 46, S886-S899. [CrossRef] [PubMed]

48. Uru, C.; Chopo, E.G.; Tommassen, J.; Mainar, J.R.C. Biofilms as Promoters of Bacterial Antibiotic Resistance and Tolerance. Antibiotics 2021, 10, 3. [CrossRef]

49. Shabib, N.A.; Husain, F.M.; Nadeem, M.; Khan, M.S.; Qurainy, F.; Alyousef, A.A.; Arshad, M.; Khan, A.; Khan, J.M.; Alam, P.; et al. Bio-inspired facile fabrication of silver nanoparticles from in vitro grown shoots of Tamarix nilotica: Explication of its potential in impeding growth and biofilms of Listeria monocytogenes and assessment of wound healing ability. RSC Adv. 2020, 10, 30139-30149. [CrossRef]

50. Husain, F.M.; Ahmad, I.; Baig, M.H.; Khan, M.S.; Khan, M.S.; Hassan, I.; Shabib, N.A. Broad-spectrum inhibition of AHL-regulated virulence factors and biofilms by sub-inhibitory concentrations of ceftazidime. RSC Adv. 2016, 6. [CrossRef]

51. Shabib, N.A.; Husain, F.M.; Ahmad, N.; Qais, F.A.; Khan, A.; Khan, A.; Khan, M.S.; Khan, J.M.; Shahzad, S.A.; Ahmad, I. Facile Synthesis of Tin Oxide Hollow Nanoflowers Interfering with Quorum Sensing-Regulated Functions and Bacterial Biofilms. J. Nanomater. 2018, 2018, 1-11. [CrossRef]

52. Shabib, N.A.; Husain, F.M.; Ahmed, F.; Khan, R.A.; Khan, M.S.; Ansari, F.A.; Alam, M.Z.; Ahmed, M.A.; Khan, M.S.; Baig, M.H.; et al. Low temperature synthesis of superparamagnetic iron oxide (Fe3O4) nanoparticles and their ROS mediated inhibition of biofilm formed by food-associated bacteria. Front. Microbiol. 2018, 9, 2567. [CrossRef]

53. Lemon, K.P.; Higgins, D.E.; Kolter, R. Flagellar Motility Is Critical for Listeria monocytogenes Biofilm Formation. J. Bacteriol. 2007, 189, 4418-4424. [CrossRef] 
54. Soo, P.C.; Horng, Y.T.; Chang, Y.L.; Tsai, W.W.; Jeng, W.Y.; Lu, C.C.; Lai, H.C. ManA is regulated by RssAB signaling and promotes motility in Serratia marcescens. Res. Microbiol. 2014, 165, 21-29. [CrossRef]

55. Gowrishankar, S.; Pandian, S.K.; Balasubramaniam, B.; Balamurugan, K. Quorum quelling efficacy of marine cyclic dipeptide -cyclo(L-leucyl-L-prolyl) against the uropathogen Serratia marcescens. Food Chem. Toxicol. 2019, 123, 326-336. [CrossRef] [PubMed]

56. Shabib, N.A.; Husain, F.M.; Ahmed, F.; Khan, R.A.; Ahmad, I.; Alsharaeh, E.; Khan, M.S.; Hussain, A.; Rehman, M.T.; Yusuf, M.; et al. Biogenic synthesis of Zinc oxide nanostructures from Nigella sativa seed: Prospective role as food packaging material inhibiting broad-spectrum quorum sensing and biofilm. Sci. Rep. 2016, 6. [CrossRef]

57. Khan, M.F.; Husain, F.M.; Zia, Q.; Ahmad, E.; Jamal, A.; Alaidarous, M.; Banawas, S.; Alam, M.M.; Alshehri, B.A.; Jameel, M.; et al. Anti-quorum Sensing and Anti-biofilm Activity of Zinc Oxide Nanospikes. ACS Omega 2020, 5, 32203-32215. [CrossRef] [PubMed]

58. Husain, F.M.; Hasan, I.; Qais, F.A.; Khan, R.A.; Alam, P.; Alsalme, A. Fabrication of Zinc Oxide-Xanthan Gum Nanocomposite via Green Route: Attenuation of Quorum Sensing Regulated Virulence Functions and Mitigation of Biofilm in Gram-Negative Bacterial Pathogens. Coatings 2020, 10, 1190. [CrossRef]

59. Lewis, O.F.; Mubarak, A.D.; Nithya, C.; Priyanka, R.; Gopinath, V.; Alharbi, N.S.; Thajuddin, N. One pot synthesis and antibiofilm potential of copper nanoparticles (CuNPs) against clinical strains of Pseudomonas aeruginosa. Biofouling 2015, 31, 379-391. [CrossRef]

60. Fux, C.A.; Costerton, J.W.; Stewart, P.S.; Stoodley, P. Survival strategies of infectious biofilms. Trends Microbiol. 2005, 13, 34-40. [CrossRef]

61. Aljaafari, A.; Ahmed, F.; Husain, F.M. Bio-Inspired Facile Synthesis of Graphene-Based Nanocomposites: Elucidation of Antimicrobial and Biofilm Inhibitory Potential against Foodborne Pathogenic Bacteria. Coatings 2020, 10, 1171. [CrossRef]

62. Kulshrestha, S.; Qayyum, S.; Khan, A.U. Antibiofilm efficacy of green synthesized graphene oxide-silver nanocomposite using Lagerstroemia speciosa floral extract: A comparative study on inhibition of gram-positive and gram-negative biofilms. Microb. Pathog. 2017, 103, 167-177. [CrossRef]

63. Gupta, S.; Afaq, F.; Mukhtar, H. Involvement of nuclear factor-kappa B, Bax and Bcl-2 in induction of cell cycle arrest and apoptosis by apigenin in human prostate carcinoma cells. Oncogene 2002, 21, 3727-3738. [CrossRef]

64. Adhami, V.M.; Ahmad, N.; Mukhtar, H. Molecular Targets for Green Tea in Prostate Cancer Prevention. J. Nutr. 2003, 133. [CrossRef]

65. Traverso, N.; Ricciarelli, R.; Nitti, M.; Marengo, B.; Furfaro, A.L.; Pronzato, M.A.; Marinari, U.M.; Domenicotti, C. Role of Glutathione in Cancer Progression and Chemoresistance. Oxid. Med. Cell. Longev. 2013, 2013, 1-10. [CrossRef] [PubMed]

66. Lash, L.; Putt, D.; Jankovich, A. Glutathione Levels and Susceptibility to Chemically Induced Injury in Two Human Prostate Cancer Cell Lines. Molecules 2015, 20, 10399-10414. [CrossRef] [PubMed] 